\title{
Direct PAyment Clauses AND THE Fraud Upon THE BANKRUPTCY LAW PRINCIPLE: RE HORIZON EARTHWORKS LTD. (BANKRUPT)
}

\author{
RODERICK J. WOOD*
}

\section{INTRODUCTION}

Bankruptcy law is overwhelmingly statutory in character. Nonetheless, there are small islands of common law rules that supplement the operation of the bankruptcy statute. One such common law rule is the principle that it is not lawful for parties to use contractual provisions to circumvent bankruptcy law. In Canada, it has been referred to as the "fraud upon the bankruptcy law” principle. The principle can be traced back to the eighteenth century in England, ${ }^{1}$ but in Canada it has been applied in only a handful of cases over the past century. The principle applied in Canada is robust in the sense that there has been virtually no change to it over this time. In contrast, there has been a rapid and recent transformation of it in England. The principle has split into two distinct subrules, and their substantive requirements have drifted ever further apart. The Alberta Court of Appeal in $R e$ Horizon Earthworks Ltd. (Bankrupt) ${ }^{2}$ applied the principle in respect of a direct payment clause in a construction contract, and the case provides an opportunity to examine how it has been applied in Canada and to compare this to the recent English developments.

\section{THE FACTS}

Horizon Earthworks Ltd. (Horizon) specialized in road construction, rough grading, and base work in northern and central Alberta. Horizon encountered financial difficulties that resulted in the appointment of a receiver manager in November 2009 and later an assignment in bankruptcy in April 2010. At the time of the appointment of the receiver manager, Horizon had several uncompleted contracts in different locations in Alberta. One of these uncompleted construction contracts was with the Municipal District of Greenview No. 16 (Greenview), which had been entered into in September of 2008. In an attempt to protect subtrades who were prohibited from filing builder's liens against a municipality, Greenview had included a provision (the direct payment clause) in the construction contract which permitted Greenview to pay the subtrades if Horizon failed to do so.

On October 2008, Horizon posted a performance bond and a labour and material payment bond, each in the amount of $\$ 761,661$. Horizon was the principal, Greenview was the obligee and trustee, and Western Surety Company (Western Surety) was the surety under these bonds. Horizon also entered into an indemnity and security agreement with Western Surety on April 2008, but Western Surety did not register a financing statement in respect of it. The Bank of Nova Scotia (the Bank) had advanced funds to Horizon through an operating line

FR (Dick) Matthews QC Professor of Business Law, Faculty of Law, University of Alberta and Estey Chair of Business Law, College of Law, University of Saskatchewan. I would like to thank Mike McCabe and Dana Nowak for providing me with a better understanding of the arguments on the trust issue that were raised before the Court of Appeal. I would also like to thank Tony Duggan for his useful comments. 
of credit. To secure the loan, Horizon entered into a general security agreement under which it granted to the Bank a security interest in all of its present and after-acquired personal property. A financing statement was properly registered in the Alberta Personal Property Registry in June 2008, thereby perfecting the security interest.

Horizon ceased work on the construction contract, and left over $\$ 900,000$ owing to creditors. Upon declaring Horizon in default under the construction contract, Greenview made a claim under the performance bond. Western Surety arranged for a third party contractor to complete the work, and this was paid for by Greenview. Western Surety also paid \$283,302.67 to unpaid creditors under the labour and materials bond. Greenview wished to pay the unsecured creditors the difference between the original contract price $(\$ 1,497,824)$ and the amounts paid by Greenview to Horizon $(\$ 723,560)$ together with the amount paid to the third party contractor $(\$ 383,000)$. Both Western Surety and the Bank objected to this payment on the ground that they were entitled to any monies that were owing to Horizon under the construction contract.

Greenview sought direction on whether it could directly pay subcontractors and suppliers of Horizon and then deduct these payments from the amounts due to Horizon under the construction contract. Western Surety claimed the funds pursuant to the terms in the indemnity and security agreement with Horizon. The Bank claimed the funds pursuant to its perfected security interest in all accounts owing to Horizon.

\section{ThE ChAMBERs Decision AND THE APPEAL}

The chambers judge held that Greenview was not entitled to pay Horizon's unsecured creditors pursuant to the direct payment clause in the construction contract. ${ }^{3}$ He observed that the Bankruptcy and Insolvency Act provides a statutory scheme of distribution under which ordinary unsecured creditors share rateably, and that giving effect to the direct payment clause would allow the parties to construct a "private reorganization" of the statutory distribution scheme. ${ }^{4}$ He held that the parties should not be permitted to make an "end-run" around the legislation. ${ }^{5}$ Under the Personal Property Security Act, ${ }^{6}$ the Bank's security interest had priority over the unsecured creditors of Horizon as well as over the unperfected security interest of Western Surety. He therefore granted the bank's application for a declaration that its security interest was entitled to priority, and ordered the funds to be paid by Greenview to the bank.

Two issues were argued on appeal to the Alberta Court of Appeal. The first was whether the chambers judge erred in determining that money payable to Horizon under the construction contract with Greenview was payable to the Bank. The second was whether the judge erred in directing the payment of money without determining how, and if, the money was owing to Horizon on the facts of the case. 
On the first issue, the Court began by noting that the contractual arrangements were utilized because of the inability of subcontractors and suppliers to file construction liens for work on public highways. It was for this reason that the construction contract contained provisions that sought to ensure that these third party claims were paid. The direct payment clause provided that Greenview "may pay directly to any claimant such amount as [Greenview] determines is owing, rendering to [Horizon] the balance due after deducting the payments so made.”7 The indemnity and security agreement between Horizon and Western Surety also contained protective provisions. Under this agreement, Horizon agreed and declared that all funds that become due under any bonded contract were trust funds held by Horizon for the benefit of the suppliers and sub-contractors.

The Court next considered the Canadian and English authorities that considered direct payment clauses. $^{8}$ The Supreme Court of Canada in AN Bail v. Gingras ${ }^{9}$ dealt with a similar provision that permitted the general contractor to pay obligations that were owed by a subcontractor in connection with the project. In this decision, the Court discussed two English decisions - In re Wilkinson, Ex parte Fowler ${ }^{10}$ and Re Tout and Finch, Ltd. ${ }^{11}$ — that appeared to uphold the validity of direct payment clauses upon a bankruptcy of the contractor. In Wilkinson, Justice Bigham emphasized the commercially desirable goals that underlie the inclusion of a direct payments clause in construction contracts. He pointed out that these clauses benefit the owner as they are able to obtain more advantageous contracts when subtrades and suppliers "know that there is a reasonable probability that they will be paid." 12 Justice Bigham also thought it relevant that the contract involved an irrevocable authorization given by the contractor that allowed the other party to pay the subtrades instead of paying the contractor. The person who owed the obligation was authorized to pay someone other than that contractor and this authorization could not be lawfully withdrawn. The implication was that if the contract authorized the payor to pay someone other than the contractor, the payor enjoyed this right both against the contractor and against the contractor's trustee in bankruptcy.

The Supreme Court of Canada in Bail held that this analysis failed to come to grips with the real issue. The question was whether the clause could supersede the statutory distribution scheme in the bankruptcy legislation. Justice Chouinard for the Court held that it could not, stating that "[i]t would be to disregard the Bankruptcy Act and deprive it of all meaning if the debtor of a bankrupt, instead of paying the trustee, were authorized, by contract or some other means, to pay one or other of the creditors of the bankrupt as he saw fit.”13

The Alberta Court of Appeal held that although Greenview was entitled to invoke the direct payment clause and pay subcontractors and suppliers before the occurrence of bankruptcy, the contractual provision could not be employed after the bankruptcy to replace

Horizon Earthworks, supra note 2 at para 33.

These authorities were not argued before or considered by the judge in Chambers.

[1982] 2 SCR 475 [Bail].

[1905] 2 KB 713 [Wilkinson].

(1953), [1954] 1 All ER 127 (Ch) [Tout and Finch].

Wilkinson, supra note 10 at 720 .

Bail, supra note 9 at 487. 
the statutory scheme of distribution provided for in the BIA. ${ }^{14}$ At the date of the bankruptcy, the debt was owed to Horizon. This debt was therefore an asset that vested in Horizon's trustee in bankruptcy, and the claims of the creditors were entitled to stand on an equal footing under bankruptcy law. The Court rejected Greenview’s argument that Bail could be distinguished by virtue of the additional documentation that created a different relationship between the parties. The Court held that, although the language in the contractual documents between Horizon and Western Surety used language that indicated that unpaid funds were to be earmarked with a trust, Greenview was not a party to those agreements and had no legal obligation to pay unpaid creditors. The obligation that Greenview owed to Horizon vested in Horizon's trustee in bankruptcy, but this was subject of the rights of any secured creditors. Although Western Surety had obtained an earlier security interest in the funds, it failed to register under the PPSA. The Bank's perfected security interest in the fund was entitled priority to the extent that any money was owed under the construction contract.

On the second issue - whether Greenview owed the money to Horizon - the Court held that the Bank's security interest in accounts only gave it a right to claim the funds if the money was due and owing to Horizon. Although the project had been completed, it was an unrelated third party that performed the remaining work. Therefore, the Court thought that there was a very live issue on whether there existed any liability on the part of Greenview to pay Horizon in light of the fact that Horizon had defaulted under the contract and that the remaining work had been performed by someone else. The Court was of the view that this question was a serious one that should not be determined in a summary manner without full argument. As the matter had not been addressed by the chambers judge, the Court allowed the appeal and directed a trial on the issue of whether Horizon was owed money by Greenview.

\section{The Operative Legal Principles}

In order to properly analyze the decision, it is necessary to examine the operative common law rules, the ongoing debates about them in England, and the recent statutory modification of these rules in Canada. Once a more complete picture is drawn, it is possible to consider the Court's approach in Horizon Earthworks.

\section{A. THE “FraUd UPON THE BANKRUPTCY LAW” PRINCIPLE}

Both the Horizon Earthworks and Bail decisions applied a principle that in Canada is sometimes referred to as the "fraud upon the bankruptcy law" principle. ${ }^{15}$ At its core, it involves the idea that it should not be lawful for parties to use contractual provisions to circumvent bankruptcy law. In Canadian Imperial Bank of Commerce v. Bramalea Inc., ${ }^{16}$ Justice Blair considered the operation of a partnership agreement that provided that upon insolvency of one of the partners, the non-insolvent partner may purchase the interest of the

14 The Court in Horizon Earthworks, supra note 2 at para 41 further observed that "[a]ny unpaid subcontractors and suppliers not paid by Greenview remain creditors of Horizon, not Greenview, under that clause."

$15 \quad$ Aircell Communications Inc v Bell Mobility Cellular Inc, 2013 ONCA 95, 2013 ONCA 95 (CanLII) at para 10; Re Laing (1921), 51 OLR 11 (SC). See also Re Westerman (Bankrupt) (1998), 234 AR 371 (QB).

16 (1995), 33 OR (3d) 692 (Gen Div) [Bramalea]. 
insolvent partner at the lesser of book value or fair market value. He expressed the principle by citing counsel's factum:

A provision in an agreement which provides that upon an insolvency, value is removed from the reach of the insolvent person's creditors to which would otherwise have been available to them, and places that value in the hands of others — presumably in a contract other than a valid secured transaction — is void on the basis that it violates the public policy of equitable and fair distribution amongst unsecured creditors in insolvency situations. $^{17}$

He held that the fraud upon the bankruptcy law principle covers cases dealing with the deprivation on an asset as well as those that involve the diversion on an asset to the favoured creditor at the expense of the other creditors. The principle applies to the forfeiture of an asset, but also to cases where another party is permitted to acquire the asset for less than its full value. Although early English authorities thought the principle required proof of actual fraud, ${ }^{18}$ Canadian decisions make it clear that this refers to "fraud in the effect" rather than "in the sense of dishonesty or impropriety."19

The Supreme Court of Canada in Bail recognized that the principle does not apply if the asset does not belong to the bankrupt or is not divisible among the creditors, as the trustee in bankruptcy will then have no right to distribute it to the creditors. The principle therefore would not apply if the bankrupt had assigned the debt to another prior to the bankruptcy. Nor would it apply if the bankrupt had agreed to hold that asset in trust for the benefit of another. ${ }^{20}$ The principle would also not apply if, on a proper interpretation of the agreement, the debt was owed to the subcontractors rather than to the bankrupt.

At one time, English decisions took a similar view of the matter. There was a single principle that applied to cases where the contractual provision attempted to withdraw an asset from the bankrupt estate as well as to cases where the contractual provision attempted to give a creditor a greater share than they were entitled to in bankruptcy. ${ }^{21}$ The 2011 decision of the Supreme Court of the United Kingdom in Belmont Park Investments Pty Ltd. v. BNY Corporate Trustee Services $L t d .{ }^{22}$ fundamentally reformulated this principle. There are now two distinct but related subrules — the anti-deprivation rule and the pari passu rule — that prevent parties from contracting out of the insolvency statutes.

\section{$17 \quad$ Ibid at 694}

18 Higinbotham v Holme (1812), 19 Ves Jr 88, 34 ER 451; In re Stephenson; Ex parte Brown, [1897] 1 QB 638 at 640 .

$19 \quad$ Bramalea, supra note 16 at 694.

20 This is of course subject to the qualification that the assignment or trust cannot be one that arises upon insolvency or the commencement of insolvency proceedings.

21 In Money Markets International Stockbrokers Ltd v London Stock Exchange Ltd, [2001] EWHC 1052, [2002] 1 WLR 1150 (Ch) [Money Markets] the traditional "fraud upon the bankruptcy law" language is used to cover both scenarios. In Perpetual Trustee Company Ltd v BNY Corporate Trustee Services Ltd, [2009] EWCA Civ 1160, [2010] Ch 347, the Court did not refer to the principle as the fraud upon

22 the bankruptcy law principle, but used "the anti-deprivation rule" terminology to cover both scenarios. [2011] UKSC 38, [2012] 1 AC 383 [Belmont]. The case involved a flip provision in a credit default swap under which the priority of the swap counterparty against a pool of assets was inverted upon an insolvency of the counterparty. This appears to be the first decision that recognizes the anti-deprivation rule and the pari passu rules as two distinct subrules. Prior to this decision, Sir Roy Goode, "Perpetual Trustee and Flip Clauses in Swap Transactions” (2011) 127 Law Q Rev 1 at 3-4 [Goode, Perpetual Trustee] had made the case for their recognition as two separate rules. 


\section{B. The ANTI-DEPRIVATion RULE}

The anti-deprivation rule operates by invalidating provisions that withdraw an asset that would otherwise be available to satisfy the claims of creditors upon the insolvency of the party or the commencement of insolvency proceedings. A classic statement of the antideprivation rule is found in Whitmore v. Mason: "no person possessed of property can reserve that property to himself until he shall become bankrupt, and then provide that, in the event of his becoming bankrupt, it shall pass to another and not to his creditors."23

The anti-deprevation rule is subject to a number of significant limitations. ${ }^{24}$ One of the earliest limitations was the distinction drawn between provisions that provide for the defeasance of an absolute interest and those that create determinable or limited interests. ${ }^{25}$ The former involve the outright transfer of an interest that is forfeited upon the occurrence of bankruptcy. These violate the anti-deprivation rule. The latter involve a determinable interest in which the quantum of the interest is "limited by the stipulated event, so that the occurrence of that event marks the end of the duration of the interest." 26 These do not violate the anti-deprivation rule. The distinction has been criticized as "little short of disgraceful" when applied to "a rule professedly founded on considerations of public policy."27 Nevertheless, the courts adhere to this distinction, and in the result leases and licences that terminate upon the occurrence of bankruptcy are unaffected, as are protective trusts that are granted by the settlor to a beneficiary until the beneficiary's bankruptcy. A second limitation on the efficacy of the anti-deprivation rule is that it only applies if the triggering event is either the insolvency of the party or the commencement of insolvency proceedings. ${ }^{28}$

The Court in Belmont held that a deliberate intention to evade the insolvency laws is required before the anti-deprivation rule is engaged. Where the parties are acting in good faith and the transaction serves a legitimate commercial purpose, the rule will not apply. ${ }^{29}$ The emphasis on good faith and a sensible commercial purpose appears to have also weakened the hold of the earlier limitations. The Court was unwilling to discard the distinction in respect of leases on the basis that it was far beyond the judicial function to do away with a 200-year-old principle. But beyond these traditional exceptions, the distinction is no longer relevant. Lord Collins thought that it was necessary to do so because of the ease with which the anti-deprivation rule could be evaded:

But it does not follow that any proprietary right which is expressed to determine or change on bankruptcy is outside the anti-deprivation rule.... If it were so, then the anti-deprivation rule would have virtually no content. This is the "flawed asset" theory, the idea that, where it is an inherent feature of an asset from the

(1861), 2 J \& H 204, 70 ER 1031 at 1034 [Whitmore].

Ibid at $1034-35$.

A thorough discussion of these authorities may be found in Money Markets, supra note 21 at paras 4786. In Canada see Re Knechtel Furniture Ltd (1985), 56 CBR (NS) 258 (Ont SC).

Belmont, supra note 22 at para 87.

In re King's Trust (1892), 29 LR Ir 401 at 410.

Belmont, supra note 22 at para 80. The anti-deprivation rule is therefore not engaged if the provision provides for termination for breach. Whitmore, supra note 23 establishes that the rule covers provisions that are triggered by insolvency as well as the commencement of insolvency proceedings.

29 In considering if the "transaction was a commercial one entered into in good faith," the court may consider the fact that the source of the bankrupt's asset is the person to whom it is to go on bankruptcy: Belmont, supra note 22 at para 98. 
inception of its grant that it can be taken away from the grantee (whether in the event of his insolvency or otherwise), the law will recognise and give effect to such a provision. If that theory were generally applicable, it would represent such an easy way of avoiding the application of the principle, that the principle would be left with little value. ${ }^{30}$

\section{The Pari Passu Rule}

Whereas the purpose of the anti-deprivation rule is to prevent the use of contractual provisions that withdraw an asset from the insolvency proceedings, thereby reducing the value of the insolvent estate to the prejudice of the creditors, the purpose of the pari passu rule $^{31}$ is to prevent the use of contractual provisions that circumvent the statutory provisions distribution and thereby gives one creditor more than its proper share. ${ }^{32}$ The pari passu rule is therefore not concerned about a net reduction in the assets available to creditors by virtue of the removal of an asset from the bankrupt estate. Instead, it is concerned with provisions that attempt to give one creditor more favourable treatment than another. Both subrules are premised on the general principle that parties cannot contract out of insolvency legislation. The difference in underlying purpose explains why some features of the anti-deprivation rule differ from the pari passu rule. The anti-deprivation rule is concerned with provisions that are triggered by insolvency or insolvency proceedings since these are the events that cause the withdrawal of the asset. The pari passu rule does not concern itself with the triggering event because its concern is how the assets of the bankrupt estate are to be distributed among the creditors.

The leading English decision on the pari passu rule is British Eagle International Air Lines Ltd. v. Compagnie Nationale Air France. ${ }^{33}$ The case involved a clearing house system for settling claims among member airlines. Under this arrangement, sums due from member airlines were netted out so as to simplify settlement of these debts. The clearing house would calculate the credit balances in respect of airlines that carried passengers for other airlines. It would also calculate debits claimed by other airlines against that airline. If the airline was in a net credit position, the clearing house would pay this amount to the airline. If it was in a net debit position, the airline would pay this amount to the clearing house. British Eagle was in a net credit position against Air France, but overall it was in a net debit position. A majority of the House of Lords held that this was an infringement of the pari passu principle

$30 \quad$ Ibid at para 89.

31 This terminology is unfortunate in that it emphasizes only one aspect of the bankruptcy scheme of distribution and the principle of collectivitiy. See Rizwaan Jameel Mokal, "Priority as Pathology: The Pari Passu Myth” (2001) 60:3 Cambridge LJ 581; Look Chan Ho, “The principle against divestiture and the pari passu fallacy” (2010) 25:1 Butterworths Journal of International Banking and Financial Law 3; Roderick J Wood, Bankruptcy and Insolvency Law (Toronto: Irwin Law, 2009) at 42. Roy Goode, Principles of Corporate Insolvency Law, 4th ed (London: Sweet \& Maxwell, 2011) at 100 states that the pari passu rule is invoked "as a form of shorthand to describe what is in fact the general statutory rule of distribution."

$32 \quad$ It is not a contravention of the pari passu rule to enter into a subordination arrangement under which the creditor agrees to receive less than the amount they would receive in bankruptcy. See In re Maxwell Communications Corporation Plc, [1993] 1 WLR 1402 (Ch); Re Air Canada (2004), 2 CBR (5th) 4 (Ont Sup Ct J).

33 [1975] 1 WLR 758 (HL) [British Eagle]. 
rule in respect of transactions that were not completed before the commencement of insolvency proceedings. ${ }^{34}$

Two earlier English authorities had validated the use of direct payment clauses in insolvency. ${ }^{35}$ In neither case was the conflict with insolvency legislation considered. Some commentators have suggested that a flawed assets theory can be used to justify the outcome in these decisions. ${ }^{36}$ The contractor obtained a right to payment that was subject to the limitation that the owner could elect to pay the subcontractors. The debt is conditional in the sense that the right to its payment by the contractor has not arisen because the owner has the right to pay it to the subcontractors. Although courts in Australia and Ireland have endorsed this view, courts in New Zealand, South Africa, Singapore, Hong Kong, and Northern Ireland have all taken the view that a direct payment clause contravenes the pari passu rule. ${ }^{37}$ Bail and Horizon Earthworks place Canada firmly within the latter camp. Many but not all commentators in England have been persuaded that British Eagle has altered the law and rendered direct payment clauses ineffective. ${ }^{38}$

A fundamental difference between the anti-deprivation rule and the pari passu rule is that considerations of good faith and legitimate commercial purpose are irrelevant in relation to the pari passu rule. ${ }^{39}$ The clearing system that was put into place in British Eagle had a sensible commercial objective and there was "no trace in the scheme of any plan to divert money in the event of a liquidation." 40 There is similarly a legitimate commercial purpose for direct payment clauses. These provisions were included in Horizon Earthworks because the subcontractors were not able to file builder's liens in respect of work that was done on highways. The contractor attempted to overcome this through the inclusion of contractual provisions that could be invoked to protect unpaid subcontractors. This was of obvious benefit to the subcontractors. It also benefited the contractor since it lessened the chance of the project being delayed because of the refusal of the subcontractor to complete the work unless paid. ${ }^{41}$

The case ultimately turned on a technical interpretation of the contractual provision. If British Eagle's right to payment was against Air France, with the clearing house merely acting as an agent in the settlement of the claims, the pari passu principle would apply with the result that the money owed to British Eagle by Air France would be available to satisfy the claims of the British Eagle's unsecured creditors. If the transaction were instead structured such that the clearing house acted as a principal so that there was no obligation owed by one airline to another airline, the pari passu principle rule would not apply as there would no longer be an obligation owed by Air France to British Eagle. The majority of the House of Lords took the first view, while the minority took the second view. The rules of the clearing house were subsequently changed so as to provide that no liability was to accrue between members of the clearing house and that all amounts were owed or owing between the clearing house and the member airlines. The Australian High Court in International Air Transport Association v Ansett Australia Holdings Ltd, [2008] HCA 3, 234 CLR 151 held that this arrangement did not violate the pari passu rule.

$35 \quad$ Wilkinson, supra note 10; Tout and Finch, supra note 11.

36 Michael G Bridge, "Collectivity, Management of Estates and the Pari Passu Rule in Winding-up” in John Armour \& Howard Bennett, eds, Vulnerable Transactions in Corporate Insolvency (Oxford: Hart, 2003) 1 at 26-30.

37 See Richard Davis, Construction Insolvency: Security, Risk and Renewal in Construction Contracts, 4th ed (London: Sweet \& Maxwell, 2011) at 545-50.

Ibid at 550-52; Goode, supra note 31 at 244-45. But see Bridge, supra note 36.

Belmont, supra note 22 at para 75.

British Eagle, supra note 33 at 763 per Lord Morris of Borth-y-Gest.

Hugh Beale et al, The Law of Security and Title-Based Financing, 2d ed (Oxford: Oxford University Press, 2012) at 353 state that direct payment clauses are designed to "avoid the substantial losses that might follow from the collapse of a complex venture." 


\section{The STATUTORY ANTI-Deprivation RULE IN THE CANADIAN INSOLVENCY LAW STATUTES}

The matter is further complicated in Canada because of the enactment, in 2009, of a statutory anti-deprivation rule in Canada's insolvency statutes. The anti-deprivation rule has been significantly modified in restructuring proceedings and in relation to bankruptcy proceedings in respect of individuals. This legislative modification of the anti-deprivation rule does not apply to bankruptcy proceedings against corporations or other artificial entities. This means that the statutory anti-deprivation rule applies in respect of commercial restructurings and consumer bankruptcies, and the common law anti-deprivation rule applies in respect of commercial bankruptcies. This legislative approach is based on provisions found in the United States Bankruptcy Code. ${ }^{42}$ These provisions regulate ipso facto clauses, which is the term used in the United States to denote contractual provisions that result in termination of a contract or a deprivation or forfeiture of an asset by virtue of an insolvency event.

Section 84.2 of the BIA provides:

(1) No person may terminate or amend — or claim an accelerated payment or forfeiture of the term under - any agreement, including a security agreement, with a bankrupt individual by reason only of the individual's bankruptcy or insolvency.

(2) If the agreement referred to in subsection (1) is a lease, the lessor may not terminate or amend, or claim an accelerated payment or forfeiture of the term under, the lease by reason only of the bankruptcy or insolvency or of the fact that the bankrupt has not paid rent in respect of any period before the time of the bankruptcy.

(3) No public utility may discontinue service to a bankrupt individual by reason only of the individual's bankruptcy or insolvency or of the fact that the bankrupt individual has not paid for services rendered or material provided before the time of the bankruptcy.

(4) Nothing in this section is to be construed as

(a) prohibiting a person from requiring payments to be made in cash for goods, services, use of leased property or other valuable consideration provided after the time of the bankruptcy; or

(b) requiring the further advance of money or credit.

(5) Any provision in an agreement that has the effect of providing for, or permitting, anything that, in substance, is contrary to this section is of no force or effect.

(6) On application by a party to an agreement or by a public utility, the court may declare that this section does not apply — or applies only to the extent declared by the court — if the applicant 
satisfies the court that the operation of this section would likely cause the applicant significant financial hardship. ${ }^{43}$

Further subsections provide that these provisions do not apply to derivatives contracts. ${ }^{44}$ Similar provisions are found in the Companies' Creditors Arrangement Act ${ }^{45}$ as well as the commercial proposal provisions of the BIA, except that these provisions are not limited to individuals but apply in insolvency proceedings against corporations and other artificial entities. $^{46}$

The statutory anti-deprivation rule is far more expansive than the common law principle. First, the traditional exclusion of determinable or limited interests such as leases and intellectual property licences is rejected. Second, in the case of leases and services provided by public utilities, the anti-deprivation rule applies to a non-insolvency triggering event in the form of a non-payment of rent or past goods and services. The common law principle, in contrast, only applies where the deprivation is triggered by insolvency or the commencement of insolvency proceedings. Third, the elements of good faith and sensible commercial purpose that are part of the English common law anti-deprivation rule are not relevant in respect of the statutory anti-deprivation rule. Fourth, the statutory anti-deprivation rule does not apply to derivatives contracts, whereas the common law anti-deprivation rule is not so limited. Fifth, the statutory anti-deprivation rule can be declared by a court to be inapplicable if the applicant satisfies the court that its operation would likely cause the applicant significant financial hardship.

\section{ANALYSIS OF THE HORIZON EARTHWORKS DECISION}

What then does Horizon Earthworks tell us about the current state of law in Canada? The decision recognizes that there is a common law rule based on public policy that prevents parties from contracting out of bankruptcy laws. Despite the fact that the rule is still referred to as the "fraud upon the bankruptcy law" principle, the Horizon Earthworks decision confirms that the current Canadian rule is not based upon any requirement of establishing fraudulent intent on the part of the contracting party. The direct payment clause served a legitimate commercial purpose and was fully operative so long as bankruptcy proceedings had not been brought. The direct payment clause was ineffective in bankruptcy because it interfered with the bankruptcy scheme of distribution, not because of any lack of good faith on the part of Greenview. The decision also rejects a "flawed asset" theory that would treat debt owing to the bankrupt as never having arisen due to the owner having been given the right to choose to pay the contractors directly instead.

In England the fraud upon the bankruptcy law principle has now been parsed into two subrules. The anti-deprivation rule covers contractual provisions that seek to withdraw an asset from the bankrupt estate, while the pari passu rule covers contractual provisions that seek to circumvent the bankruptcy scheme of distribution by giving a creditor more than their share. The real significance of the modern English approach is that the anti-deprivation rule 
is now based on considerations of good faith and sensible commercial purpose, while the pari passu rule is based on effect rather than intent. Thus, one of the subrules has returned to its earlier roots and is concerned with fraudulent intent, while the other subrule views intent as irrelevant. Horizon Earthworks provides little guidance on whether Canadian courts are likely in the future to embrace the English anti-deprivation rule. To the extent that it recognizes a single principle grounded in consideration of public policy covering both types of cases, this suggests that the principles that animate both types of cases are the same. On this view, the case provides some support for the view that fraudulent intent plays no role in either type of case in Canada. On the other hand, Horizon Earthworks was concerned with a contractual provision that altered the bankruptcy scheme of distribution - the pari passu rule. It therefore might be argued to have no bearing on whether Canadian courts will be receptive to the English anti-deprivation rule.

This debate about the common law anti-deprivation rule might have been rendered moot by the enactment of a statutory anti-deprivation rule that applies to all insolvency proceedings. ${ }^{47}$ However, Parliament chose not to enact the provision in respect of bankruptcies of corporations and other artificial entities, and the common law rule will therefore continue to operate in cases that involve a commercial bankruptcy as opposed to a restructuring. The statutory anti-deprivation rule has its own unique quirks — notably the ability of a court to order its inapplicability based upon its financial effect on the applicant - but it is clearly based on the effect of the transaction and not on the intent of the contracting party. The unresolved question in Canada is therefore whether the common law principle that operates in commercial bankruptcies will be effects-based or intent-based.

The most problematic feature of Horizon Earthworks is its analysis of the traditional exception based on trust or assignment that brings the case outside the ambit of the common law rule. Neither the anti-deprivation rule nor the pari passu rule applies where the asset has been assigned or made subject to a valid trust before the commencement of bankruptcy proceedings. In the case of an assignment or transfer, the common law rule does not apply because the property is no longer the property of the bankrupt at the date of the bankruptcy proceedings. ${ }^{48}$ In the case of a trust, there is no deprivation or alteration of the bankruptcy distribution rules because the BIA expressly provides that trust property is not divisible amongst the creditors.

The contract between Greenview and Horizon did not provide that Horizon was to hold the funds in trust. The trust provisions were found in the bonding arrangements between Horizon and Western Surety. The Court of Appeal dealt with this issue in the following paragraph:

In our view, the contractual arrangements here do not establish a relationship sufficient to distinguish Bail.

Although there is language in the contracts between Horizon and Western Surety relating to unpaid funds

47 This assumes that the legislative anti-deprivation provision was intended to displace the common law rule. If this is not the case, then the safe harbour created in respect of derivatives contracts would protect these contracts from the statutory anti-deprivation rule, but not from the common law anti-deprivation rule. It seems unlikely that the legislators would have intended this result.

48 It may be possible to impeach the transaction as a transfer at undervalue or preference, but this engages a different set of statutory rules. See BIA, supra note 4, ss 95-96. 
being earmarked with a trust, Greenview is not a party to the Bonds or the ISA, and has no legal obligations under any of those agreements to pay unpaid creditors. While the Labour and Material Payment Bond says that Greenview, as Obligee under the Bonds, can bring claims on behalf of unpaid creditors, it does not require Greenview to do so. Nothing in any document places an obligation on Greenview to pay the unpaid creditors. Thus, if Greenview owes money to Horizon at bankruptcy pursuant to the Harper Creek Contract, that account receivable becomes the property of the Trustee. ${ }^{49}$

The Court appears to be proceeding on the basis that the contractual documents between Horizon and Western Surety had designated Greenview as the trustee, but that Greenview was not a party to this agreement. Although this appears to be the case in respect of the labour and materials bond, the provisions of the indemnity and security agreement make it clear that Horizon additionally was declaring a trust in favour of the subcontractors in respect of funds that were owed to it by Greenview. In any event, the Court's conclusion on this point does not undermine the principle that an assignment of the debt or a declaration of a trust in favour of another will bring the matter outside the ambit of the fraud upon the bankruptcy laws principle. The Court simply found that a trust had not been validly constituted on the particular facts of the case at hand.

One further point should be made. Greenview would not, by any means, be out of the woods if it were able to convince a court that the fraud upon the bankruptcy laws principle did not apply because it held the funds in trust for the subcontractors. The issue would then arise whether this trust in substance constituted a security interest so as to require registration under the $P P S A .^{50}$ If it did constitute a security interest in the form of a trust, its lack of registration would render it effective against the trustee in bankruptcy. ${ }^{51}$ Even if it was considered to be a true trust, a further issue would arise as to the resolution of a priority competition between a trust and a security interest. Although the trust would have arisen before the bank obtained its security interest, the bank could argue that it was entitled to priority on the basis that it was a bona fide purchaser of a legal interest for value and without knowledge of the trust. ${ }^{52}$

\section{CONCLUSION}

In one respect, an abandonment in Canada of the archaic fraud upon the bankruptcy laws language in favour of a common law anti-deprivation rule and a pari passu rule would be a useful development in that it would more sharply focus on the different reasons for the invalidation of the contractual provision. Roy Goode ${ }^{53}$ and Sarah Worthington ${ }^{54}$ have both argued that the recognition of this division is crucial in order to understand the differing objectives of the two subrules. It is important to note that neither have argued that this recognition justifies the approach to good faith and commercial purpose taken by the Supreme Court of the United Kingdom in Belmont. Indeed, Worthington argues that the decision has emasculated the anti-deprivation rule and that this will produce a dramatic

Horizon Earthworks, supra note 2 at para 43.

See Re Skybridge Holidays Inc (1998), 11 CBR (4th) 126 (BC SC).

PPSA, supra note 6, s 20(a).

See $i$ Trade Finance Inc v Bank of Montreal, 2011 SCC 26, [2011] 2 SCR 360.

Goode, Perpetual Trustee, supra note 22.

Sarah Worthington, "Good Faith, Flawed Assets and the Emasculation of the UK Anti-Deprivation Rule” (2012) 75:1 Mod L Rev 112. 
increase in "defensive drafting” as parties seek to protect their deprivation provisions. ${ }^{55}$ Other English commentators have characterized the good faith safe harbor as "unacceptably obscure." 56

To date, Canadian courts have not displayed any interest in breaking down the fraud on the bankruptcy law principle into these two separate rules. The danger in doing so is that Canadian courts might go further and apply Belmont without carefully examining whether there exists a convincing explanation why the common law anti-deprivation rule should protect good faith dealings that seek a commercially sensible objective, whereas the pari passu rule should view such considerations as irrelevant. The Canadian fraud upon the bankruptcy law principle presently applies to both types of cases, and Canadian courts have held that this refers to "fraud in the effect" rather than "in the sense of dishonesty or impropriety." 57

The Horizon Earthworks decision makes it clear that the pari passu portion of the common law principle will be applied with its full vigour in Canada. What remains to be seen is if the anti-deprivation rule portion will follow the same trajectory as in England and revert to a rule concerned with actual fraud. ${ }^{58}$ Even if Canadian courts reject this aspect, they may nevertheless be attracted to other aspects of the English approach. In particular, they may be receptive to the idea that the artificial distinction between defeasance of an absolute interest and those that create determinable or limited interests should no longer prevail, except in cases where the exception has been long recognized. This would bring the antideprivation aspect of the common law principle rule more in alignment with the statutory anti-deprivation rule in the Canadian insolvency law statutes.

Predictions about the future are notoriously unreliable, but we can reasonably anticipate that Canadian insolvency lawyers will raise Belmont in their arguments and that courts will then need to decide whether to follow this new path. Recognizing the existence of two distinct rules is beneficial in that it properly focuses the inquiry. The insolvency-related triggering event is the critical element in the case of the anti-deprivation rule. The contractual provisions that contravene the pari passu rule typically do not involve an insolvency-related triggering event. Rather, the contracting party's right to invoke a contractual provision after the commencement of bankruptcy proceedings is lost because it interferes with the scheme of distribution mandated by bankruptcy law. Moreover, the recognition of two separate common law rules is likely inevitable now that we have enacted a statutory anti-deprivation rule that covers only part of the terrain.

\section{$55 \quad$ Ibid at 121}

Beale et al, supra note 41 at 350 .

Bramalea, supra note 16 at 694 . The case involved the removal of an asset rather than an alteration of the bankruptcy scheme of distribution, so the case would clearly fall within the anti-deprivation rule of Belmont.

$58 \quad$ Some Canadian commentators are attracted to the approach in Belmont. See Margaret Grottenthaler \& Elizabeth Pillon, "Financial Products and the Anti-Forfeiture Principle” (2012) $1 \mathrm{~J}$ of the Insolvency Institute of Canada 139 at 159: "intention to adversely affect creditors of the insolvent party is a critical element of the analysis" in relation to preferences and transfers at undervalue, and it "would be a significant departure from bankruptcy principle to void transactions with a valid commercial purpose based on a mechanical application of a broad principle, particularly one not codified in what is already very detailed legislation." 
But there it should end. Canadian courts should not take the further step and follow Belmont in adopting an intent-based test in respect of the anti-deprivation rule. This is clearly contrary to existing Canadian decisions that do not require proof of actual fraud in cases involving insolvency triggered forfeiture. A move to an intent-based anti-deprivation rule is difficult to justify given that the new statutory anti-deprivation rule clearly adopts an effectsbased test. An even better solution would be to amend section 84.2(1) so that it covers all bankrupts and not just bankrupt individuals. The US Bankruptcy Code ${ }^{59}$ does not limit its anti-deprivation provisions in this way, and the Canadian approach appears to proceed from a mistaken assumption that the primary purpose of the rule is to enhance the fresh start policy afforded to the individual debtor. This would simplify matters considerably. The end result would be a statutory anti-deprivation rule that would apply in all insolvency proceedings, and a common law pari passu rule that would apply in bankruptcy. ${ }^{60}$ 